Anatoliy KRUGLASHOV, Andriana KOSTENKO*

\title{
PUBLIC OVERSIGHT OF UKRAINE'S EUROPEAN INTEGRATION COURSE
}

\begin{abstract}
The article deals with the wide range of mechanisms in support of civil society institutions-government interaction in the context of developing and implementing European integration reforms in Ukraine. The authors identified 6 strategic documents and 20 areas of reform related to the process of European integration, as well as the key issues concerning implementation of the Association Agreement between Ukraine and the $E U$. The authors conclude that positive trends are visible in recent decades in the institutional development of Ukrainian civil society, which has become a driving force of the country's European integration aspirations. In this setting, civil society institutions (CSIs) work with government agencies, engage in informal advocacy, conduct monitoring policies, perform and publish policy analysis and recommendations, and work with and lobby international agencies and other actors.
\end{abstract}

Keywords: Ukraine; European integration; European integration reforms; public control

\section{Introduction}

Ukraine took the path of forming its statehood in 1991. In a short while, the country chose a liberal-democratic model for its political system and identified European integration as a strategic priority. In the years since independence was proclaimed, the country has made some progress in terms of socio-economic and political reforms capable of bringing it closer to the European Union. However, the implementation of systemic reforms and holistic Europeanisation of the country still require considerable concerted efforts from society and the government. A critical role here should be attributed to civil society institutions interested in Ukraine's success in its European integration trajectory.

* Anatoliy Kruglashov, PhD, Professor, Yuriy Fedkovych Chernivtsi National University, Ukraine, Andriana Kostenko, PhD, Associate Professor, Sumy State University, Ukraine. 
Civil society has quite often saved the country from sliding into authoritarianism in domestic policy and the corresponding model of Eurasian integration in foreign policy (Solonenko, 2015: 219-236). When the cooperation between the authorities and the active public has been the most constructive, Ukraine has achieved the considerable significant success. For example, this also applies to the EU-Ukraine Association Agreement where, contrary to the will of President V. Yanukovych and his political environment, civil society defended Ukraine's choice of Europe, despite having paid a heavy price by way of the victims of the 2014 Revolution of Dignity and the counteraction to the Russian aggression, which is continuing today (Maass, 2019). Yet, there is still a long way to establish a steady and fruitful partnership between public authorities and local self-government on one hand and civil society institutions (CSIs) on the other (Puglisi, 2017: 41-61).

Therefore, an important research objective of the article is to study the state-public partnership experience, starting by studying regulatory support for sustainable and productive dialogue between authorities and citizens, and concluding with an analysis of the key forms and methods of CSIs' impact on developing and implementing state policy. The authors concentrate on changes that emerged following the Revolution of Dignity 184 (between 2014 and 2018), taking account of the process of civic society's revitalisation after the crucial changes experienced by Ukraine, and looking at the research object through the prism of implementation of the EUUkraine Association Agreement.

Public control is relatively new for Ukraine as a form of social influence and provides for direct monitoring by civil society institutions, initiative groups and individuals of the (in)activity of state authorities and local government, as well as the (in)activity of non-governmental institutions that perform social tasks (Kostenko, 2018). Public control covers a range of different forms and instruments of influence that can be applied, depending on the goals and objectives. It is quite apparent that independent and effective public control can only be exercised in democratic countries where civil and political rights are appropriately secured.

\section{Theoretical framework}

In scientific analysis, conceptual approaches to the study of civil society are apparent due to the lack of research aimed at studying modern theoretical approaches to determining the role of civil society institutions, and CS' impact on the processes of European integration and implementation of reforms.

Our study is based on the views of Alexis de Tocqueville, who showed the connection between and identity of civil society and democracy. He notes the formal existence of all bodies and institutions of democratic power in 
the political system does not guarantee its democratic nature. An essential component of civil society is setting traditions and habits to think and act under democratic norms and principles (Tocqueville, 2000: 412-418). Tocqueville assigns a unique role to civil society, which is to overcome the powerlessness of an individual; moral and socio-psychological influence on the state; forming "local and personal freedom"; creating an active social field; spreading the spirit of solidarity, tolerance, and cooperation, as well as creating a "keen public eye" that constantly monitors the government and does not allow its tyranny.

In turn, John Keane proposes viewing civil society through the prism of concepts like power, property, violence, politics, the public sphere, and democracy. In his work "Civil Society: Old Images, New Vision," the author rethinks democracy in the context of changes at the end of the 20th century in Central and Eastern Europe. His idea of the need for the parallel development of civil society institutions and the state is noteworthy.

Democracy is always a complex, constantly growing process of proportional division of powers and civilian control over its use in politics, carried out in two institutionally distinct, but constantly connected spheres of civil society and state institutions. (Keane, 2000: 113)

L. Diamond considers civil society as an indispensable condition for democracy and a necessary factor for democratic transformations and achieving the consolidation of democracy. He notes that in the process of such a merger, changes occur in the institutional development and behaviour of people, which normalises the democratic political process and makes it stable and predictable.

Therefore, this normalisation requires expanding people's access to political decision-making, developing a democratic political culture, enlarging the circle of leaders, improving their training level, and developing other functions specific to civil society. To implement the economic, political and social reforms seen in countries that have decided to follow democratic development, political parties and active state institutions are also needed. However, as Diamond notes, it is "civil society that can and should be crucial in building a consolidated democracy" (Diamond, 1999: 239).

According to Habermas, the $\mathrm{S}$ (civil society) is called upon to both exercise control over the state by restraining it from encroaching on the personal, political, cultural, public freedom of the citizens and over capital (Habermas, 1998). R. Putnam's research traces the link between the efficiency of state institutions and the level of civil society development, which is one of the main factors for success in implementing democratic reforms (Putnam, 1993: 35-42). 
For instance, Marjan Horvat offers the prospect of the study of European integration rooted in methodological pluralism and assertion of the subjective dimension which, according to the author, is required while analysing the post-crisis EU and all of its political differences (Horvat, 2019: 547-564).

There is scientific interest in studying the state and role of CS in Eastern Europe. In particular, the impact of European integration on institutionalisation of the CS is considered. Together with domestic governments, international donors and the EU are perceived to be the most influential institutional actors for CS organisations. Yet, their respective influences primarily depend on a country's stage in its EU accession process. Overall, the study provides a differentiated mapping of civil society in Eastern Europe and a better understanding of how the institutional context relates to a country's CS (Meyer, 2020).

The European dimension of Ukraine's course towards the EU has been covered in many works, for example, by A. Gavrikh, R. Dragnev, I. Horha, P. Kubicek, A. Umland, J.W. Scott and others. However, public control over state bodies and the implementation of the Association Agreement in Ukraine are insufficiently represented in scientific research.

\section{The EU-Ukraine Association Agreement is a Road Map} for Reforms

By signing the Association Agreement with the European Union, Ukraine committed itself to implementing the reforms required for its further successful European integration. The EU-Ukraine Association Agreement (Agreement) has thereby become a road map for internal transformational changes in Ukraine. By its scope and thematic coverage, the Agreement has become the largest international legal document in the history of Ukraine and, at the same time, the biggest international treaty with a third country ever concluded by the EU. The Agreement provides for the implementation of more than 350 EU directives and regulations, while the Agreement Action Plan outlines all of the derivative tasks. Such a clear definition gives an opportunity to understand its execution status, and to plan and define additional guidelines.

Among measures that determine the commonality of domestic political needs and tasks for improving Ukraine's political system as defined by the European integration course, the following may be specified: overcoming the contradictions of democracy and improving its functioning; taking measures to eliminate the most serious violations in parliamentary democracy; reducing bureaucracy; shortening the deputy mandate period, ensuring the influence on parties from outside through research institutes, foundations etc.; strengthening the development of local government; gradual implementation of the primaries model etc. (Andreychenko, 2017). 
The main strategic documents shaping the directions of the European integration reforms in Ukraine are the EU-Ukraine Association Agreement; the Sustainable Development Strategy "Ukraine 2020"; the Coalition Agreement; the IMF-Ukraine Memorandum; the Government Priority Action Plan; and the Plan of Legislative Support for Reforms. We will not extensively describe each of these documents here as they are not the subject of our study. Nevertheless, it is noted that on the basis of this legal framework Ukraine has identified 20 priority reform areas, which largely determine its further European perspective. These areas include: public administration reform; decentralisation; innovation development; business climate improvement (deregulation, investments, export); state property management reform; energy reform and energy efficiency development (Bayramov and Marusyk, 2019); infrastructure and transport; healthcare reform; education and science reform; social support reform; anti-corruption reform; law enforcement reform; judicial reform; national security and defence reform (Jayasundara-Smits, 2018); labour relations reform; temporarily occupied territories and support for internally displaced persons (IDPs) as well as youth, culture, sports (see Table 1).

Table 1: THE STRUCTURE OF EUROPEAN INTEGRATION REFORMS

\begin{tabular}{|c|c|}
\hline 6 strategic documents & 20 areas of reform \\
\hline $\begin{array}{l}\text { - The UA-Ukraine Association } \\
\text { Agreement } \\
\text { - Sustainable Development Strategy } \\
\text { "Ukraine 2020" } \\
\text { - Coalition Agreement } \\
\text { - The IMF-Ukraine Memorandum } \\
\text { - The Government Priority Action } \\
\text { - Plan } \\
\text { - The Plan of Legislative Support } \\
\text { for Reforms }\end{array}$ & $\begin{array}{l}\text { - } \text { Public administrative reform } \\
\text { - } \text { Decentralisation } \\
\text { - Innovation development } \\
\text { - } \text { (deregulation, investment, exports) } \\
\text { - } \text { Energe property management reform } \\
\text { - } \text { Infrastructure and transport } \\
\text { - Healthcare reform } \\
\text { - Reform of education and science } \\
\text { - Reform of social support system } \\
\text { - Anti-corruption reform } \\
\text { - Law enforcement reform } \\
\text { - Judicial reform } \\
\text { - Reform of the national security and defence } \\
\text { - } \text { Rystem } \\
\text { - Temorm of the labour relations system } \\
\text { - for IDPs } \\
\text { Youth, Culture, Sport }\end{array}$ \\
\hline
\end{tabular}

Source: Compiled by the authors.

Our study does not focus on content analysis of the above-mentioned EU integration reforms, but on exploring the mechanisms for public control over their implementation. Our interest lies not so much in the mechanisms of direct democracy (non-conventional methods) which can be employed 
by CSIs in collaboration with state authorities and local self-government, but in the wide range of conventional mechanisms for CSI-government interaction, on both national and regional/local levels in the context of developing and implementing a number of European integration reforms in Ukraine.

It should be mentioned that national and local governance bodies are the main actors and executing agents when it comes to the development and implementation of state policy generally and reforms in particular. Yet, as stated above, several legal and regulatory instruments oblige (not simply empower) government and local authorities to set up the necessary environment to ensure the transparency of such a policy and to enable CSIs to join in all stages of the implementation and control.

In accordance with the EU-Ukraine Association Agreement, it has been declared that CSIs participate in enforcement of the Agreement's terms "in order to inform about the implementation of this Agreement and to allow for the contribution of civil society organizations to its implementation" (Government Portal, 2017). In particular, the Agreement provides for establishing a Civil Society Platform composed of representatives of Ukrainian civil society on one hand, and members of the European Economic and Social Committee (EESC) on the other, as a forum for holding relevant meet188 ings and exchanging views.

Active participation of the public in urgent reforms is necessary for the successful and timely implementation of the Association Agreement. The EU and Member States are developing CSI interaction road maps supposed to intensify and assure a structural dialogue and strategic joint cooperation, enhance capacities and influence on governance decisions and political actions. In cooperation with the governments of partner countries, the EU tries to extend the ability of government bodies to constructively collaborate with CS by increasing trust and competencies for dialogue and partnership opportunities. These road maps are also intended to facilitate coordination and share best practices with Member States and other international actors to simplify, in particular, procedures and harmonise funding requirements. Road maps set long-term goals for EU-CSIs collaboration that include dialogue as well as operational assistance, and provide appropriate mechanisms. They are developed with a view to CS demands being regularly updated and published, as well as submitted to national governments.

Wide support and full CS involvement in the European integration processes provide the legitimacy of the changes needed and reinforce them. Thus, according to the Government report on implementation of the Association Agreement for 2018, the Agreement compliance rate was 52\%. It was highlighted that the Agreement tasks not completed in previous years were being gradually fulfilled, and the overall result of the Agreement's implementation was growing considerably (Report, 2018). Positive changes 
in the field of decentralisation and civil service reform were achieved in 2018, coupled with some achievements in financial transparency etc. At the same time, several problems remain to be resolved: insufficient institutional capacity of the ministries, resistance to reforms by individual interest groups, the irresponsible attitude of some elected officials to the political intentions of the EU movement declared by their political forces. This together with other reasons prevent the timely and full completion of Agreement assignments.

\section{The Role of Civil Society in Implementing the EU Integration Reforms}

After the events of Euromaidan in Ukraine, definite trends may be seen in the institutional development of Ukrainian CS. In particular, we analysed CSIs in terms of their organisational and financial solvency through the following indicators: quantitative characteristics of CSI development; ensuring democratic, accountable, transparent internal governance; economic sustainability and diversification of funding sources; improving the mechanisms for interaction with authorities.

Recently in Ukraine, an increase has been observed in the number of officially registered public organisations. Judicial authorities register about 70,000 public organisations in Ukraine, of which 66\% are local, all-Ukrainian and international public organisations, $0.3 \%$ are political parties, and 31\% are local, all-Ukrainian and international charitable organisations (Ukrstat, 2017).

The rapid growth of CSIs may be linked to growth in their financial support received from international institutions, non-governmental organisations, and foreign countries' national governments. Yet, the public funding for CSIs is quite limited. The annual budget of the average Ukrainian public organisation is about UAH 50,000-60,000 (around EUR 3,000), and the primary income is mainly provided by local benefactors and foreign donors. Data on NGO funding sources indicate the existence of two main group entities. The first group is characterised by a working model where funding from external sources is a significant supporting factor. Still, up to $30 \%$ of funding comes from the organisation's services and other economic activities. The preferential financing model from charitable contributions and grant funds is typical for the second cluster of organisations. As a result, the further sustainable development of such entities is significantly influenced by macro-environmental factors (Ukrstat, 2017).

The chief sources of NGO funding are grants and technical assistance programmes funded by other countries (from non-residents). Having analysed the map of attracting international aid (International Aid, 2015), we see that all available programmes/projects and international development 
policy documents are helping Ukraine to meet its international obligations, stabilise the socio-economic situation, and strengthen CS. The support for CS organisations is aimed at ensuring their active participation in democratic change and making them more effective in defending the rights and interests of citizens and exercising public control with regard to the authorities' actions.

Analysing the positive dynamics of the increase in NGOs, one cannot ignore the negative trends of the expanding quasi-organisations used by specific political forces to lobby their activities, organise pseudo-protests, manipulate public opinion, and advisory structures under the government. At the same time, this situation can be explained by the specific nature of the existence of a particular part of officially registered public associations, the lack of real work to involve ordinary citizens in their activities. In turn, we will only focus on the successful interaction practices between the CSIs and the authorities while implementing European integration reforms in Ukraine. It is noted that the activities of quasi-organisations will be the subject of our next study.

The analysis of Ukrainian NGOs' capacity demonstrates many obstacles that are limiting the influence of CS on government policy in Ukraine, such as:

- the low financial self-sufficiency of CSIs and limited financial resources;

- the lack of motivation mechanisms concerning NGO financial support by business, for example through interest-rate philanthropy mechanisms;

- the provision of NGOs with services is more visible and practical on the local level, while most policy development activities take place on the national level;

- the number of coalitions is increasing, but their actions are not coordinated and not established, and effective governance and management procedures have not been established;

- the unwillingness of the authorities to cooperate and their bias against CSIs;

- the weak connection of public organisations with the population, lack of solidarity, conflict, inability to find shared understanding;

- the lack of a holistic system of civic education, efficient promotion of democratic values, public consciousness;

- insufficient level of systematic support for the dialogue between the authorities and interested CSIs in various areas;

- the low development level of participatory democracy and activation of communities to solve their development problems;

- the presence of 'pocket' public organisations (under government bodies, parties, oligarchs); and

- insufficient opportunities to involve citizens in the activities of NGOs and their weak connection with the general public. 
Despite the specified negative circumstances and certain obstacles, the role played by domestic CSIs in facilitating the reform of the state governance system is today quite important. In particular, this idea is highlighted by experts from the international non-governmental organisation Freedom House (Freedomhouse, 2018) in its study "Nations in Transit 2018. Confronting Illiberalism".

Indeed, CSIs work with governmental agencies, engage in informal advocacy, accomplish monitoring studies and make their results public, provide political analysis and make practical recommendations based on its results, as well as carry out other activities (Lutsevych, 2016: 646-656). They are also active in training and in-service training of civil servants and decision-makers, collaborate and lobby (in Ukraine or abroad) with international agencies and other political actors in order to influence the field policy. They also raise public awareness through media, education and training, arrange social events and public debates, organise or encourage protests (Kostenko, 2018). The institutional formats for involving CSIs in the processes of European and Euro-Atlantic integration are mainly composed of the following elements:

- coalitions of non-governmental organisations, as well as actions, projects and programmes focused primarily on addressing European integration issues;

- coalitions, actions, projects and programmes that concentrate on other issues related to European integration;

- analytical and consultative activities, in particular in public councils, expert groups and other institutions formed by NGOs at central and local governments where the issues of Ukraine's European integration are under consideration (Kruglashov, 2016: 53-65).

In this article, the authors will dwell chiefly on the first format and partly the second one. As to the third format, it has already received the widest possible coverage in the academic literature (Khutkyy, 2019; Kruglashov, 2013; Savchenko, 2015; Zheltovskyy, 2019), although not through research focused on the European integration aspects of the analytical and advisory role of CSIs in cooperation with the public authorities of Ukraine.

On the national level, CSIs have been successful in creating coalitions to increase their own power and strengthen their influence on the government. Thus, a Reanimation Package of Reforms (RPR) group consisting of 70 civil organisations was formed to exert pressure on the country's new administration and to introduce its own reform plan for Ukraine. Other active groups have created coalitions such as "Public Partnership for Transparent Local Budgets", "Civic Initiatives of Ukraine", "Our Money", "New Country" etc. Organisations like as the Center for Combating Corruption (CPC) and 
Transparency International have been playing a significant role in creating a new anti-corruption infrastructure that includes new government bodies: the National Anti-Corruption Bureau of Ukraine (NABU) and the National Agency on Corruption Prevention (NACP). With respect to building a new judicial system, a Ukrainian innovation was to establish the Public Integrity Council (GRD), formed from representatives of CS and the educational and scientific community. This independent body has to check judges for their compliance with ethical and professional integrity criteria (Ash, 2017: 77). Thus, as we can see, European integration processes in Ukraine have become the condition and determining factor that stimulates not only the development of CS as a whole, but also creates opportunities for its genuine impact on democratic transformation in particular.

It must be recognised that in Ukraine the sector of "watch organisations" is only now in the process of formation, methodology is being developed and standards of public control are being established. Thus, Transparency International Ukraine (TI Ukraine) is one of the first organisations in Ukraine to systematically deal with the problem of combating corruption in public authorities. Its documents state that its mission is to reduce corruption in Ukraine by means of promoting the transparency, accountability and 192 integrity of public authorities and civil society (Transparency International Ukraine). Namely, TI Ukraine has assumed the role of conducting promotional campaigns on the national level which are supposed to reduce the community's tolerance to corruption, citizens' awareness of its danger and negative impacts. While playing this role, TI Ukraine conducted the following communications campaigns between 2014 and 2016: "Wake up! Corruption kills!" "They would not be silent", "Corruption should be noticed", "I do not give bribes", "We demand the creation of an anti-corruption court".

Another powerful anti-corruption NGO is the Center for Combating Corruption (CPC). According to an analysis of its performance found on the $\mathrm{CPC}$ website, the main directions of its work are monitoring public procurement and exposing corruption schemes. That is, the above-mentioned organisation is engaged in direct supervisory activities. Its report analysis shows the CPC has managed to terminate government corruption contracts in state structures amounting to approximately UAH 1.9 billion (Human Rights NGO's Anti-Corruption Platform), resulting in the initiating of 150 criminal proceedings (UA-Energy.org).

The CPC is also actively working on developing and lobbying for anticorruption legislation, which has enabled the creation of what are fundamentally new to Ukraine: special anti-corruption bodies of the National Anti-Corruption Bureau of Ukraine (NABU), Specialised Anti-Corruption Prosecutor's Office (SAP), and the National Agency of Ukraine for Finding, Tracing and Managing Assets Derived from Corruption and Other Crimes. 
This testifies to the efficiency of public influence on the sensitive areas of governance and the new opportunities for CSIs in this area.

Another organisation whose activity attracts our attention is the NGO "Anti-Corruption Headquarters" that aims to expose corruption schemes, the plundering of budgets and resources in local communities, and other corruption-related violations of power-holders in order to prosecute them (Anti-Corruption Headquarters). As is evident, this NGO works not only on the national level but also on the regional and local ones, paying considerable attention to corruption on the community level. Since decentralisation processes in Ukraine have resulted in quite a substantial inflow of budgetary allocations to local government baselines, especially in the case of newly formed united territorial communities, the close public attention to the legitimacy and transparency of their financial activities thus far is more than justified. According to this organisation, due to public procurement in 2017, companies affiliated with MPs (members of the Ukrainian Parliament) received tenders amounting to UAH 4.1 billion, that is, 12,500 procurements, while 423 MPs account for 2,400 companies related personally to them or their relatives.

At the same time, $94 \%$ of tenders won by MPs did not involve any competition (Interfax-Ukraine, 2017). Thus, it is only from this information that we can make an inference about the enormous scope of anti-corruption tasks, which remain an urgent challenge for public authorities and NGOs in Ukraine.

Among projects of the "Anti-Corruption Headquarters" is the "Hidden Interests" initiative aimed at identifying officials" illicit wealth and conflicts of interest. This initiative is a database of companies directly or indirectly related to Kyiv City Council deputies, officials of the Kyiv City State Administration and district administrations. On the organisation's website, one can find documents such as a transcript or the agenda of a City Council meeting and discover certain matches, if any, between the database and a document (Knyazhansky, 2017).

Among NGOs which engage in analytical work and participate in the elaboration of anticorruption policy, the most notable is the Center for Political and Legal Reforms, which provides public anticorruption expertise for socially significant bills. Second place is taken by the Center for Political Studies and Analytics "Eidos". The latter includes an anti-corruption department involved in introducing and studying issues concerned with access to public information, the use of public funds, operation of local councils, decision-making processes and the access of citizens to participate in those processes (Kornievsky, 2018: 74.).

One of the common forms of public control is public expertise. Public expertise is the only type of public control that has been introduced in Ukraine as an authorities-community feedback technology, and is currently 
the most common tool for the public to influence the government. In particular, the Center for Political and Legal Reforms has revealed dozens of acts that entailed corruption risks during the public anti-corruption expertise of potentially high-risk draft laws submitted to the Verkhovna Rada of Ukraine (Center for Political and Legal Reforms, 2018).

Another common and frequently employed control mechanism is public monitoring - i.e. the planned and systematic gathering of information on a specific issue or the activity of public bodies, following a clear framework (methodology) in order to ensure positive changes. In the process of its realisation, the focus is on evaluating the effectiveness and efficiency of a state body, a local self-government body, a public agency and other public institutions. It is carried out by a public control entity by means of collecting and analysing publicly available information on their activities over a certain period of time.

For example, CS is active in monitoring Ukraine's fulfilment of its commitments under the EU-Ukraine Association Agreement. This role is evidenced by the report "From Goals to Results: Implementing the Association Agreement through the Eyes of Stakeholders" (Civic Synergy), prepared by the Ukrainian side of the EU-Ukraine Civil Society Platform and supported

194 by the "Public Synergy" project. Experts provided a wide range of recommendations according to the monitoring results (Kostenko, 2018):

1. To give proper regard to the complete and effective implementation of the Association Agreement's provisions, including the 'soft' obligations (where there are no requirements to harmonise legislation with the EU's legal acts).

2. To conduct audit ("screening") of the current Ukrainian legislation for its compliance with international and European law. To turn to the EU for help in realising this task, as well as to involve representatives of the stakeholders and Ukrainian non-state experts.

3. To inform the stakeholders about the process of developing decisions, conducting events and their results.

4. To introduce systematic monitoring of the progress of the planned reforms, including the implementation efficiency of the new legislative regulations after their adoption.

5. To analyse the Ukrainian and international experience with practical implementation of the state's strategic documents (in the areas of water management, combating discrimination, support for innovations and science, the information society, consumer protection).

6. To introduce training programmes on the specialisations required and to conduct the in-service education of employees and workers (in the areas of basin management, consumer protection, prevention of discrimination). 
7. To budget financial instruments and funds needed for implementation of the Agreement. To provide the necessary financial and organisational support for the National Council of Ukraine for the Development of Science and Technology, the National Research Fund, the scientific programme for supporting implementation of basin management and vocational education councils. To audit the research infrastructure of public research institutions and universities.

Recently, such tools for the public's influence on authorities such as holding public hearings, especially on the local level, the submission of e-petitions, public participation budgets etc., have also become widespread. Still, these mechanisms are applied by CS with different levels of engagement, and it is somewhat premature to write about their proven effectiveness on the national scale.

\section{Conclusion}

As we have observed, diverse mechanisms for public control are being formed in Ukraine and are currently in operation and already somewhat institutionalised. A fairly wide range of opportunities for the public to exert an impact on state policy from national to local levels is specified in national laws and regulations. These opportunities are subsequently expanded and enriched, primarily due to the development of e-democracy tools. Analysis of the legal framework shows the lack of a comprehensive approach to understanding the concept of public, civil society and civil society institutions. These terms are not defined in the laws, which leads to terminological confusion, the lack of their uniform application in different legal documents and, accordingly, inconsistencies in the legal regulation of these areas. Further, a large number of CSIs' initiatives in the field of public control are conspicuous in the public space. Most of these are not supported by domestic actors, but by international funds and grants, which allows fewer opportunities for CSIs and impoverishes their agenda in this direction, while restricting their influence on government policy. Especially prevalent are public control measures in the sphere of monitoring within the context of the Association Agreement or the implementation of European integration reforms, anti-corruption measures. While its generally possible to talk about the increasing influence of public control instruments on the quality of European integration policy, this influence is still volatile and unsystematic in nature. Although CSIs use a broad range of public control mechanisms and methods for assessing government actions and decisions in the European integration context, their recommendations are often ignored by national and local authorities. This situation is explained by the lack of a settled tradition of interaction between 
them, the fragility of the CSIs themselves, and the reluctance of authorities to take the recommendations that emerge into account. Taking all of this into consideration, CSIs often come up with initiatives with international partners and thus, through enhanced external pressure, attempt to make up for the gap in the partner relationship with public authorities and influence the reform process in the country. The latter practice should be regarded as not fully effective when one assumes further needs and the outlook for the processes of European integration and democratic reforms in Ukraine. However, in order to cope with it, a new quality of CSI activity is required and, under its influence, a significant renewal of the national political and governance elite.

\section{BIBLIOGRAPHY}

Andreychenko, A. (2017): Європейський вибір як чинник модернізації українського суспільства. The European Choice as a Factor in the Modernization of Ukrainian Society. Scientific journal of NP Dragomanov 22: 91-96. Accessible at http:// enpuir.npu.edu.ua/bitstream/123456789/19352/1/Andrieichenko\%2C\%20A.. pdf.

Ash, T., J. Gunn, J. Lough, O. Lutsevych, J. Nixey, J. Sherr and K. Wolczuk (2017): The Struggle for Ukraine. Chatham House Report - London. Accessible at https://www.chathamhouse.org/sites/default/files/publications/research/201710-18-struggle-for-ukraine-ash-gunn-lough-lutsevych-nixey-sherr-wolczukV5. pdf.

Bayramov, A. and Y. Marusyk (2019): Ukraine's Unfinished Natural Gas and Electricity Reforms: One Step Forward, Two Steps Back. Eurasian Geography and Economics 60 (1): 73-96.

Diamond, L. (1999): Developing Democracy: Toward Consolidation. The Global Resurgence of Democracy. Baltimore, The John Hopkins University Press.

Habermas, J. (1998): Between Facts and Norms. Cambridge, Mass.

Jayasundara-Smits, S. (2018): From Revolution to Reform and Back: EU-Security Sector Reform in Ukraine. European Security 27 (4): 453-468.

Keane, J. (2000): Громадянське суспільство: старі образи, нове бачення. Civil Society: Old Images, New Vision. Kyiv. 113.

Khutkyy, D. (2019): Electronic Democracy in Belarus, Moldova, and Ukraine. Patterns and Comparative Perspectives. Südosteuropa 67 (2): 264-284.

Knyazhansky, V. (2017): У пошуках прихованих інтересів. In search of hidden interests. Accessible at http://day.kyiv.ua/uk/article/ekonomika/u-poshukah-pryhovanyh-interesiv.

Kornievsky, O. (Eds). (2018): Громадянське суспільство України: сучасні практики та виклики розвитку : аналіт. доповідь. Civil society of Ukraine: current practices and challenges of development: analyte. report. Kyiv. 74.

Kostenko, А. (2018): Вплив інститутів громадянського суспільства на євроінтеграційні процеси України: монографія. The Influence of Civil Society Institutions on Ukraine's European Integration Processes: Monograph. Sumy: Sumy State University. 
Kruglashov, A. (2013): Громадські Ради як комунікатор між вцадою та організованою громадськістю: регіональний досвіА та потенціал в: Аержава і громадянське суспільство в Україні: пошук концепції співпраці: аналітична доповіА. Public Councils as a Communicator between Government and Organized Public: Regional Experience and Potential in: State and Civil Society in Ukraine: Searching for the Concept of Cooperation: An Analytical Report. Mayborody, O. (Ed). Kyiv: IPIEND. 132-155.

Kruglashov, A. (2016): Hardships of Dialogue: Civil Society Communication with Authorities in Ukraine. Der Donauraum 56 (1-2): 53-65.

Lutsevych, O. (2016): Civil Society versus Captured State: A Winning Strategy for Sustainable Change. Development in Practice 26 (5): 646-656.

Maass, A.-S. (2019): From Vilnius to the Kerch Strait: Wide-ranging Security Risks of the Ukraine Crisis. European Politics and Society 20: 609-623.

Meyer, M., C. Moder, M. Neumayr et al. (2020): Civil Society and Its Institutional Context in CEE. Voluntas 31: 811-827.

Puglisi, R. (2017): Institutional Failure and Civic Activism: The Potential for Democratic Control in Post-Maidan Ukraine, Reforming Civil-Military Relations in New Democracies. Springer: 41-61.

Putnam, R. (1993): The Prosperous Community. Social Capital and Public Life. The American Prospect 4 (13): 35-42.

Savchenko, O. (2015): Громадські ради як суб’єкт здійснення громадського контролю в Україні: правові засади й тенденції розвитку. Public Councils as a Subject of Public Control in Ukraine: Legal Principles and Development Trends. Legal Bulletin 1: $67-72$.

Solonenko, I. (2015): Ukrainian Civil Society from the Orange Revolution to Euromaidan: Striving for a New Social Contract. OSCE Yearbook 2014: 219-236.

Tocqueville A. (2000): Про демократію в Америці. About Democracy in America. Kyiv. 412-418.

Zheltovskyy, V. (2019): Civil Society as an Actor in the Political Processes of Local Governance Reform in Ukraine. Środkowoeuropejskie Studia Polityczne 2: 83-104.

\section{SOURCES}

Anti-corruption headquarters. Accessible at https://shtab.net/en/pages/view/pronas, 23. 2. 2021.

Centre of Policy and Legal Reform. Accessible at http://pravo.org.ua/ua/news/ 20872550-antikoruptsiyna-ekspertiza-zakonoproektiv, 23. 2. 2021.

Civic Synergy (2017). From Objectives to Results: The Implementation of the EUUkraine Association Agreement as Seen by Stakeholders. Accessible at https:// www.civic-synergy.org.ua/en/analytics/from-objectives-to-results-the-implementation-of-the-eu-ukraine-association-agreement-as-seen-by-stakeholders/, 23. 2. 2021.

Freedomhouse (2018): Nations in Transit 2018 Confronting illiberalism. Accessible at https://freedomhouse.org/report/nations-transit/2018/ukraine 1, 23.02.2021.

Human Rights NGO's Anti-Corruption Platform. Accessible at http://akp.prava-lyu- 
dyny.org/about-corruption/anticorruption/antikoruptsijni-gromadskiorganiza tsiji/24-tsentr-protidiji-koruptsiji.html. 23. 2. 2021.

Interfax-Ukraine (2017): Больше всего госзакупок в 2017 г. выиграли компании нардепов от Воли народа, Оппоблока и БПП. The most public purchases in 2017 were won by the people's deputies of the Will of the People, Oppoblock and BPP. Accessible at https://interfax.com.ua/news/press-conference/508733.html, 23. 2. 2021.

Government Portal (2015): International Aid Attraction Map. Accessible at https:// www.kmu.gov.ua/storage/app/media/uploaded-files/karta-dopomogi-26-062015.pdf, 23. 2. 2021.

Government Portal (2017): Association Agreement between the European Union and Ukraine. Accessible at https://www.kmu.gov.ua/en/yevropejska-integra ciya/ugoda-pro-asociacyu, 23. 2. 2021.

Report 2018 on Implementation of the Association Agreement between Ukraine and the EU. Accessible at http://www.3dcftas.eu/documents/other/2018-reportimplementation-association-agreement-between-ukraine-and-eu.

Transparency International Ukraine. Accessible at https://ti-ukraine.org/about, 23. 2. 2021.

UA-Energy.org. Who leads the anti-corruption movement in Ukraine? List of the largest anti-corruption projects. Accessible at https:/ua-energy.org/en/posts/ 27-09-2017-7f36026e-3cc4-4f5e-8f25-ad78435b7870, 23. 2. 2021.

Ukrstat (2017): Аіяльність громадських організацій в Україні. Аоповідь. Activities of Public Organizations in Ukraine. Report. Accessible at http://www.ukrstat.gov. ua/druk/publicat/kat_u/publpolit_u.htm, 23. 2. 2021. 